\title{
CLINICAL AND EPIDEMIOLOGICAL FINDINGS DURING A MEASLES OUTBREAK OCCURRING IN A POPULATION WITH A HIGH VACCINATION COVERAGE
}

\author{
Solange Artimos de Oliveira, Walquíria Nascimento Soares, Marcos Olivier \\ Dalston, Maria Teresa G.N. de Almeida and Antonio José L. Costa
}

\begin{abstract}
From March 1991 to April 1992, 250 measles suspected cases were studied in the Municipality of Niterói, State of Rio de Janeiro. The median age found was 11 years and 76.0\% of the cases were in scbool age children. Exposure bistories were present in 149 patients and schools were the most frequent sites of transmission (45.0\%). Vaccination status was known for 127 studied cases and $76.4 \%$ of them bad received measles vaccine before their first birtbday. One or more complications were reported for 68 cases and in $8.9 \%$ of the studied cases bospitalization was required. Frequency of complications varied according to each age group studied and were more commonly encountered among cbildren < 1 year of age (55.6\%). The history of previous vaccination did not diminish the number of complications of the cases studied. The results of this work show changes in age distribution of measles leading to sizeable outbreaks among teenagers and young adults.
\end{abstract}

Key-uıords: Measles epidemiology. Vaccine failure. Measles complications.

In countries where measles vaccination has reached high levels some changes in disease epidemiology have been observed, and among them, a progressive upward shift in the age distribution of measles incidence towards older children ${ }^{820}$. This increase in the mean age of occurrence of measles cases is related to population vaccination coverage levels. Recently, many authors have reported measles outbreaks in teenagers and adults, and in some cases including people previously vaccinated $^{711} 1222$.

Despite the differences found in the vaccination coverage levels among the States of Brazil, the number of measles notified cases in recent epidemics did not reach the same levels observed in the 70's. This fact is due to the progressive increase in the vaccination coverage levels in the last years and the impact

\footnotetext{
Disciplina de Doenças Infecciosas e Parasitárias da Universidade Federal Fluminense, Niterói, RJ e Fundação Municipal de Saúde de Niterói, RJ, Brasil.

Supported by CNPq grant $\mathrm{n}^{\circ} 501840 / 91-5$ and PROPP/Universidade Federal Fluminense.

Address to: $\mathrm{Dr}^{\mathrm{a}}$ Solange Artimos de Oliveira. Disciplina de Doenças Infecciosas e Parasitárias, Hospital Universitário Antonio Pedro. R. Marquês do Paraná $303 / 2^{\circ}$ andar, 24033-210 Niterói, RJ, Brasil, Fax: (021) 717-4459.

Recebido para publicação em 10/02/95.
}

of vaccination campaigns on the incidence of the disease ${ }^{513}$.

Until 1984 the epidemiology of measles in the Municipality of Niterói, State of Rio de Janeiro, was characterized by high morbidity and mortality rates, mainly reported in children under five. Since 1985, following the introduction of national immunization campaigns mainly directed to children $9-23$ months of age, measles incidence and mortality have declined rapidly. However, it has been observed that the mean age of reported cases increased each year ${ }^{5}$.

Measles incidence in Niterói began to increase during the 90's, but at this time most of the cases were observed in children from 10 to 14 years of age, followed by those from 5 to 9 years of age. Although the age group at the highest risk continues to be children of less than one year of age, an increase in the proportion of measles cases has occurred in older childrens. A similar picture has been described by other authors, mainly in countries that have achieved and sustained high coverage rates ${ }^{711422}$.

This paper reports the investigation of an outbreak of measles in a population with a high vaccination coverage. 
Oliveira SA, Soares WN, Dalston MO, Almeida MTGN, Costa AJL. Clinical and epidemiological findings during a measles outbreak occuring in a population with a bigh vaccination coverage. Revista da Sociedade Brasileira de Medicina Tropical 28:339-343, out-dez, 1995.

\section{MATERIAL AND METHODS}

Study design. The study was conducted in Niterói, State of Rio de Janeiro, Brazil. From March 1991 to April 1992 an intensive surveillance system was instituted by the Division of Epidemiology of Niterói Department of Health. Physicians were required to report suspected measles cases immediately, based on the criteria established by the Centers for Diseases Control ${ }^{4}$ as a clinical case: an illness characterized by fever $\geq 38.3^{\circ} \mathrm{C}$, generalized maculopapular rash of a 3 days-duration and, at least one of the following: cough, coryza or conjunctivitis. Each case reported to the Department of Health was followed up by a review of the case record and investigated by epidemiologists or nurses of the Department of Health especially trained to confirm clinical diagnosis. In order to find additional cases all health workers were instructed to ask patients about the presence of rash-like illness occurring in their neighbourhood as well as among school colleagues.

A questionnaire containing the personal data, signs and symptoms of measles, vaccination history, setting of transmission, and complications was designed for the study. Only persons with a well-documented history of prior immunization were assumed to be vaccinated. All of them had received a live, attenuated measles vaccine.

A history of exposure to measles was defined as a known contact with a case 8 to 18 days before the onset of the disease.

Statistical analysis. Frequency distributions were analysed by the chi-square test and the differences considered significant at the 0.05 level.

\section{RESULTS}

During the study period 290 patients out of a total of 293 notified cases were considered as having clinical measles after reviewing by the Health Department of the Municipality of Niterói. The majority of suspected cases (250 $86.2 \%$ ) were investigated by epidemiologists or nurses of the Department of Health to collect information according to the questionnaire designed for this study. Only investigated cases were included in this analysis.

The median age was 11 years (range, 5 months to 31 years) and $76.0 \%$ of the cases were in the school-age children ( 5 to 19 years of age). Patients $\geq 10$ years of age accounted for $60.0 \%$ of all studied cases (Table 1).

Table 1 - Distribution by age and sex of 250 measles case investigated in the Municipality of Niterói. State of Rio de Janeiro.

\begin{tabular}{lcr}
\multicolumn{3}{c}{ investigated in the Municipality of Niterói. State of Rio de Janeiro. } \\
\hline Age distribution by age groups (years) & $\mathrm{Nr}$ & $\%$ \\
$\quad<1$ & 18 & 7.2 \\
$1-4$ & 30 & 12.0 \\
$5-9$ & 52 & 20.8 \\
$10-14$ & 96 & 38.4 \\
$15-19$ & 42 & 16.8 \\
$\geq 20$ & 12 & 4.8 \\
Sex & & \\
male & 113 & 45.2 \\
female & 137 & 54.8 \\
\hline
\end{tabular}

Exposure bistories. A history of exposure to measles was present in 149 (59.6\%) patients. The most frequently reported sites of transmission were: school: $67(45.0 \%)$ cases; home: 47 (31.5\%) cases; neighbourhood: 24 (16.1\%) cases and others: $11(7.4 \%)$ cases. Setting of transmission varied according to age. The most frequently reported contacts for children $<5$ years of age were the home and neighbourhood, and among patients from 5 to 19 years of age, school and home. The relation school/home increased according to age.

Vaccination status. Vaccination status was known for $127(50.8 \%)$ studied cases and 97 (76.4\%) of them had been vaccinated before their first birthday. The other 30 (23.6\%) patients had received measles vaccine on or after one year of age (14 cases received one dose and 16 cases received two or more doses). All the children $<1$ year of age were unvaccinated. The remaining 123 patients were unvaccinated or had a poor documented history of prior vaccination.

Complications of measles. One or more complications were reported for $68(27.2 \%)$ cases, including pneumonia in 37 (54.4\%), otitis media in $22(32.4 \%)$, diarrhea in 12 $(17.7 \%)$, and others (sinusitis, laryngitis, tonsilitis) in $8(11.8 \%)$. No case of encephalitis was seen. Frequency of complications varied according to each age group studied (Table 2). They were more commonly encountered among children $<1$ year of age and those of the age group from 15 to 19 years old. A total of $22(8.9 \%)$ hospitalizations were required by measles complications. 
Oliveira SA, Soares WN, Dalston MO, Almeida MTGN, Costa AJL. Clinical and epidemiological findings during a measles outbreak occuring in a population with a bigb vaccination coverage. Revista da Sociedade Brasileira de Medicina Tropical 28:339-343, out-dez, 1995.

Table 2 - Proportion of measles cases with complications, by age group. Niterót, State of Rio de Janeiro*

\begin{tabular}{ccrc}
\hline $\begin{array}{c}\text { Age group } \\
\text { (in years) }\end{array}$ & $\mathrm{Nr}$ & \multicolumn{2}{c}{ Complications } \\
\cline { 3 - 4 }$<1$ & 18 & $\mathrm{nr}$ & $\%$ \\
$1-4$ & 30 & 8 & 55.6 \\
$5-9$ & 52 & 12 & 26.7 \\
$10-14$ & 96 & 21 & 23.1 \\
$15-19$ & 42 & 15 & 21.9 \\
$\geq 20$ & 12 & 2 & 35.7 \\
Total & 250 & 68 & 27.2 \\
\hline
\end{tabular}

$P=0.056, X^{2}=10.77$

Frequency of complications also varied according to previous vaccination status (Table 3). They were seen more frequently in unvaccinated cases $(33.3 \%)$ than in those vaccinated $(21.3 \%)$. This result was statistically significant $\left(\mathrm{x}^{2}: 4.60-\mathrm{P}<0.05\right)$. The relation between complications and history of previous vaccination were also analysed without including children $<1$ year of age (Table 4). Although they continued to be seen more frequently in unvaccinated cases (29.5\%) than in those vaccinated (21.3\%), this result was not statistically significant anymore $\left(x^{2}: 2.09-P>\right.$ 0.05).

Table 3 - Frequency of complications according to vaccination status".

\begin{tabular}{lrcrcc}
\hline Vaccination & \multicolumn{2}{c}{ Complications } & \multicolumn{2}{c}{ Without complications } & Total \\
\multicolumn{1}{c}{ Status } & $\mathrm{nr}$ & $\%$ & $\mathrm{nr}$ & $\%$ & $\mathrm{nr}$ \\
\hline Vaccinated & 27 & 21.3 & 100 & 78.7 & 127 \\
Unvaccinated & 41 & 33.3 & 82 & 66.7 & 123 \\
\hline Total & 68 & & 182 & & 250 \\
\hline
\end{tabular}

"P $<0.05, \mathrm{X}^{2}=4.60$

Table 4 - Frequency of complications according to vaccination status without including children $<1$ year of age?

\begin{tabular}{lccccc}
\hline \begin{tabular}{l} 
Vaccination \\
\multicolumn{1}{c}{ status }
\end{tabular} & \multicolumn{2}{c}{ Complications } & \multicolumn{2}{c}{ Without complications } & Total \\
Vaccinated & $\mathrm{nr}$ & $\%$ & $\mathrm{nr}$ & $\%$ & $\mathrm{nr}$ \\
Unvaccinated & 27 & 21.3 & 100 & 78.7 & 127 \\
Total & 31 & 29.5 & 74 & 70.5 & 105 \\
\hline
\end{tabular}

${ }^{*} \mathrm{P}>0.05, \mathrm{X}^{2}=2.09$

\section{DISCUSSION}

In the USA, from 1984 to $1988,58 \%$ of reported cases affected children $\geq 10$ years of age, compared with 10\% during the period 1960 to $1964^{3}$. This progressive upward shift in the age distribution of measles incidence towards older children has been reported by foreign authors ${ }^{620}$, and also in our country ${ }^{513}$. This fact was confirmed in this work, where the median age for the period studied was 11 years. The proportion of cases among children from 10 to 14 years of age $(38.4 \%)$ exceeded the one among children from 1 to 4 and from
5 to 9 years old together $(32.8 \%)$. Furthermore, the proportion of cases among people from 15 to 19 years old $(16.8 \%)$ was higher than the proportion found in children from 1 to 4 years old $(12.0 \%)$, the age group of highest incidence before the beginning of vaccination campaigns 5 .

The changes in the age distribution of measles incidence can be related to some factors: a) Because of the mass campaign vaccination, the number of susceptible children under the age of 5 decreased and the measles cases that occur in adolescents and adults came to represent a great percentage of all reported cases ${ }^{2}$. b) The decrease of measles transmission in the community caused by vaccination also protected indirectly unvaccinated people (herd immunity). So, many of them became older without having contact with the measles virus, either natural or by vaccination ${ }^{2} 19$

Another factor that can be responsible for the changes of measles epidemiology is that vaccine induced immunity can wane with time $^{11}$. Krugman ${ }^{10}$ believes that waning immunity may be insignificant from the epidemiologic point of view and that adequate immunization is sufficient to protect more then $95 \%$ of the vaccinated children over a long period.

However, the increase of measles cases in previously vaccinated children has been described by different authors ${ }^{6}>112122$. The reasons of vaccine failure can be related to: neutralization of vaccine virus by maternal antibodies or those artificially administered (gamma globulin) ${ }^{15}{ }^{20}$; improper storage or handling vaccine leading to inactivation of live virus $^{916}$ 17; "primary vaccine failure", which occurs in about $5 \%$ of vaccines ${ }^{18}$

In Brazil, because of the high incidence of measles at a young age, routine measles vaccine has been recommended for children 9 months of age or older since 1982. As 13-15\% of the children remain susceptible with this strategy, a few States decided to administer a second dose of the vaccine after 15 months of age $^{13}$. Nevertheless, this policy was not adopted for the country as a whole, leading to insufficient levels of vaccine coverage to attain disease control.

In this study vaccinated status was known in $127(50.8 \%)$ studied cases and a total of 97 $(76.4 \%)$ were vaccinated before their first 
Oliveira SA, Soares WN, Dalston MO, Almeida MTGN, Costa AJL. Clinical and epidemiological findings during a measles outbreak occuring in a population with a bigh vaccination coverage. Revista da Sociedade Brasileira de Medicina Tropical 28:339-343, out-dez, 1995.

birthday. The other $30(23.6 \%)$ patients had received measles vaccine at or after one year of age. The high percentages of people vaccinated with only one dose before their first birthday could explain vaccine failure. Moreover, alterations in measles vaccine quality could also have contributed to the results related above. Oliveira et al, in $1986^{16}$ and in $1990^{17}$, carried out an investigation to evaluate the basic procedures involved in the storage of measles vaccine in public health units of the Municipality studied. The first research showed that all vaccine sample titers were well below the minimal recommended potency by the manufacters. Four years later, despite the improvement of the cold chain when compared to the former evaluation, $55.2 \%$ of the vaccine samples were still under the minimal recommended potency.

Transmission in schools accounted for 67 (45.0\%) of 149 cases with a history of measles, followed by homes ( 47 cases $31.5 \%$ ) or neighbourhood (24 cases - 16.1\%). Moreover, transmission in schools was more frequent for people from 5 - 19 years of age. The highest proportion in these settings can be explained because students transmit infection more efficiently than younger children. They frequently visit other classrooms and attend social events outside the school, which bring large groups together ${ }^{6}$. It was particularly interesting to observe that transmission in medical settings (hospitals, emergency rooms, and physicians' offices), found in only one case in this study, had not so much importance as the one observed by Manson et al. ${ }^{12}$ and Atkinson et a ${ }^{1}$ in the USA, in $18.9 \%$ and $18.4 \%$ of their cases, respectively.

Despite the high percentage of complications $(27.8 \%)$ verified during the period studied, no case of death caused by measles was reported. Furthermore, no case of measles - associated death has been notified to Niterói Health Department since 1987, which is according to the high levels of vaccination coverage obtained over the last years, mainly in children under 5 years old ${ }^{5}$. As it was expected, complications were more commonly encountered among children under 1 year of age $(55.6 \%)$, but high rates were also found in other age groups. In spite of these high rates only $8.9 \%$ of the patients were hospitalized with one or more complications of the disease. The hospitalization rates found here are well lower than those verified by Manson et al." and Atkinson et $\mathrm{al}^{1}$ in the USA, 44.3\% and $26.4 \%$ of their cases, respectively. The less severe measles cases observed are probably due to the change in the age distribution and the increasing median age of reported cases. The history of previous vaccination did not diminish the number of complications of the cases studied.

The results of this study show changes in the epidemiology of measles in the Municipality of Niterói, mainly in the last three years. All the facts here discussed, as vaccination strategies adopted and causes of vaccine failures, may have contributed to these results. Therefore, to attain measles control it is important to continue the efforts to increase vaccination coverage, and to expand active surveillance of the disease.

\section{RESUMO}

No periodo de março de 1991 a abril de 1992, 250 casos de um total de 293 notificados como sarampo em Niterói, RI foram estudados. Em 75,9\% dos casos o sarampo ocorreu em pessoas de idade escolar (mediana: 11). História de exposição estava presente em 149 pacientes. O local de transmissão variou de acordo com a idade sendo a escola o mais freqüentemente encontrado (45\%). Em 127 casos o estado vacinal era conbecido e $76,4 \%$ deles tinbam sido vacinados antes do primeiro aniversário. Em 68 casos uma ou mais complicações estavam presentes e em 8,9\% deles a bospitalização foi necessária. Complicaçōes foram mais freqüentes em menores de um ano de idade $(55,6 \%)$. História de vacinação prévia não diminuiu o nümero de complicações dos casos estudados. Os resultados deste trabalbo mostram mudanças na epidemiologia do sarampo, com alterações na distribuiçãa etâria dos casos da doença, levando à ocorrência de importantes surtos da virose entre adolecentes e adultos jovens.

Palauras-chaves: Epidemiologia do sarampo. Falha de vacinação. Complicações do sarampo.

\section{ACKNOWLEDGEMENT}

This work would not be possible without the aid of the health workers from the Municipality of Niterói, State of Rio de Janeiro.

\section{REFERENCES}

1. Atkinson WL, Hadley SC, Redd SB, Orenstein WA. Measles Surveillance - United States. 1991. 
Oliveira SA, Soares WN, Dalston MO, Almeida MTGN, Costa AJL. Clinical and epidemiological findings during a measles outbreak occuring in a population with a bigh vaccination coverage. Revista da Sociedade Brasileira de Medicina Tropical 28:339-343, out-dez, 1995.

Morbidity and Mortality Weekly Report 41:1-12, 1992.

2. Barata PCR, Leal MC. Distribuição etária do sarampo e vacinação: considerações sobre alguns dados do Município do Rio de Janeiro. Cadernos de Saúde Pública 1:50-57, 1985.

3. Centers for Diseases Control. US Public Health Service. Measles surveillance report no. 11, 1977 1981. Atlanta, Georgia, 1982.

4. Centers, for Diseases Control. Measles; Washington, 1990. Morbidity and Mortality Weekly Report 39:473-6, 1990.

5. Fundação Municipal de Saúde de Niterói. Superintendência de Ações de Saúde. Departamento de Epidemiologia e Controle de Agravos. Informe Epidemiológico - Sarampo p.18, 1992 .

6. Gustafson TL, Lievens AW, Brunell PA, Moellenberg RG, Buttery CMG, Schulster LM. Measles outbreak in a fully immunized secondary - school population. The New England Journal of Medicine 316:771-774, 1987.

7. Judelsohn R, Fleissner ML, O' Mara DJ. School based measles outbreaks: Correlations of age at immunization with risk of disease. American Journal Public Health 70:1162-1165, 1980.

8. Krause PJ, Cherry JD, Deseda-Tous J, Champion JG, Strassburg M, Sullivan C, Spencer MJ, Bryson YJ. Welliver RC, Boyer KM. Epidemic measles in young adults. Annals of Internal Medicine 90:873$876,1979$.

9. Krugman RD, Meyer BC, Parkman PD, Wittle J, Meyer HM. Impotency of live - virus vaccines as a result of improper handling in clinical practice. The Journal of Pediatrics 91:512-514, 1974.

10. Krugman S. Present status of measles and rubella immunization in the United States. A medical progress report. The Journal of Pediatrics 78:1, 1971.

11. Linnemann Jr CC, Rotte TC, Schiff GM, Youtsey JL. A seroepidemiologic study of a measles epidemic in a highly immunized population. American Journal of Epidemiology 95:238-246, 1972.

12. Manson WH, Ross LA, Lanson J, Wright Jr HT. Epidemic measles in the postvaccine era: evaluation of epidemiology, clinical presentation and complications during an urban outbreak. The Pediatric Infectious Disease Journal 12:42-48, 1993.
13. Ministério da Saúde. Fundação Nacional de Saúde. Capacitação de Pessoal para a Vigilância Epidemiológica do Sarampo. Módulo Institucional 1. Brasília p. 1-77, 1992

14. Nagy G, Kósa S,Takátsy S, Koller M.The use of IgM tests for analysis of the cause of measles failures: experience gained in an epidemic in Hungary in 1980 and 1981. Journal of Medical Virology 13:93103,1984 .

15. Oliveira SA, Homma A, Camillo-Coura L, Loureiro MLP, Almeida MTGN. Antimeasles antibodies in children submitted to different vaccination schedules. Revista da Sociedade Brasileira de Medicina Tropical 26:77-82, 1993.

16. Oliveira SA, Homma A, Mahul DC, Loureiro MLP, Camillo-Coura L. Avaliação das condições de estocagem da vacina contra o sarampo nas unidades sanitárias dos Municípios de Niterói e São Gonçalo - Estado do Rio de Janeiro. Revista do Instituto de Medicina Tropical de São Paulo 33:313-318, 1991.

17. Oliveira SA, Loureiro MLP, Kiffer CRV, Maduro LMF. Re-evaluation of the basic procedures involved in the storage of measles vaccine in public health units of the Municipality of Niterói, State of Rio de Janeiro, Brazil. Revista da Sociedade Brasileira de Medicina Tropical 26:145$149,1993$.

18. Plotkin SA. Failures of protection by measles vaccine. The Journal of Pediatrics 82:908-911, 1973.

19. Schaffner W, Schlederberg AES, Byrne EB. Clinical epidemiology of sporadic measles in a highly immunized population. The New England Journal of Medicine 279:783-789, 1968.

20. Shasby M, Shope TC, Downs H, Herrmann KL, Polkowski J. Epidemic measles in a highly vaccinated population. The New England Journal of Medicine 296:585-589, 1977.

21. Smith FR, Curran AS, Raciti AK, Black FL. Reported measles in person immunologically primed by prior vaccination. The Journal of Pediatrics 90:391-393, 1982

22. Wyll SA, Witte JJ.Measles in previously vaccinated children.An epidemiological study. The Journal of American Medical Association 216:1306-1310, 1971 